\title{
Expression of Neuroserpin, an Inhibitor of Tissue Plasminogen Activator, in the Developing and Adult Nervous System of the Mouse
}

\author{
Stefan R. Krueger, ${ }^{1}$ Gian-Piero Ghisu, ${ }^{1}$ Paolo Cinelli, ${ }^{1}$ Thomas P. Gschwend, ${ }^{1}$ Thomas Osterwalder, ${ }^{1}$ \\ David P. Wolfer, ${ }^{2}$ and Peter Sonderegger ${ }^{1}$ \\ Departments of ${ }^{1}$ Biochemistry and ${ }^{2}$ Anatomy, University of Zurich, $\mathrm{CH}-8057$ Zurich, Switzerland
}

\begin{abstract}
Neuroserpin is a serine protease inhibitor of the serpin family that has been identified as an axonally secreted glycoprotein in neuronal cultures of chicken dorsal root ganglia. To obtain an indication for possible functions of neuroserpin, we analyzed its expression in the developing and the adult CNS of the mouse. In the adult CNS, neuroserpin was most strongly expressed in the neocortex, the hippocampal formation, the olfactory bulb, and the amygdala. In contrast, most thalamic nuclei, the caudate putamen, and the cerebellar granule cells were devoid of neuroserpin mRNA. During embryonic development, neuroserpin mRNA was not detectable in neuroepithelia, but it was expressed in the differentiating fields of most CNS regions concurrent with their appearance. In the cerebellum, the granule cells and a subgroup of Purkinje cells were neuroserpinpositive during postnatal development. As a further step toward
\end{abstract}

the elucidation of neuroserpin function, we performed a study to identify potential target proteases. In vitro, neuroserpin formed SDS-stable complexes and inhibited the amidolytic activity of tissue plasminogen activator, urokinase, and plasmin. In contrast, no complex formation with or inhibition of thrombin was found. Expression pattern and inhibitory specificity implicate neuroserpin as a candidate regulator of plasminogen activators, which have been suggested to participate in the modulation or reorganization of synaptic connections in the adult. During development, neuroserpin may attenuate extracellular proteolysis related to processes such as neuronal migration, axogenesis, or the formation of mature synaptic connections.

Key words: neuroserpin; serine protease inhibitor; plasminogen activator; plasmin; thrombin; central nervous system; synaptogenesis; neuronal plasticity
Serine proteases have been implicated in a variety of processes during nervous system development. Thrombin is known to inhibit and reverse neurite outgrowth in cell culture (Gurwitz and Cunningham, 1988) and may participate in activity-dependent synapse elimination at the neuromuscular junction (Liu et al., 1994). Plasminogen activators (PAs), secreted from growth cones of extending neurites (Krystosek and Seeds, 1981, 1984), modulate neurite outgrowth in vitro (Pittman et al., 1989; Pittman and DiBenedetto, 1995), and may also facilitate neuronal migration (Moonen et al., 1982; Friedman and Seeds, 1995). Recently, a function of PAs in synaptic plasticity and memory formation has been suggested. Tissue plasminogen activator (tPA) mRNA levels are increased in the hippocampus on induction of long-term potentiation (LTP) (Qian et al., 1993) and in the cerebellum after learning of a complex motor task (Seeds et al., 1995). In line with these observations, it has been reported that the release of tPA from PC12 cells is dependent on membrane depolarization and calcium influx (Gualandris et al., 1996). Moreover, mice deficient in tPA exhibit an interference in long-lasting LTP (Frey et al., 1996; Huang et al., 1996) and show an impaired performance in a two-way active avoidance learning paradigm (Huang et al.,

\footnotetext{
Received April 22, 1997; revised Sept. 15, 1997; accepted Sept. 17, 1997.

This work was supported by the Wolfermann-Nägeli-Stiftung, the Bonizzi-ThelerStiftung, the Stipendienfonds der Basler Chemischen Industrie, and the Union Bank of Switzerland on behalf of a client. We thank Dr. Beat Kunz for help in generation of monoclonal antibodies, Drs. Anke Krebber and Andreas Plückthun for the expression vector pAK400, Genentech (South San Francisco, CA) for recombinant tPA, and Dr. Hans-Peter Lipp for providing generous access to equipment.

Correspondence should be addressed to Peter Sonderegger, Department of Biochemistry, University of Zurich, Winterthurerstrasse 190, 8057 Zurich, Switzerland Copyright (c) 1997 Society for Neuroscience $0270-6474 / 97 / 178984-13 \$ 05.00 / 0$
}

1996). On the other hand, mice overexpressing urokinase (UPA) in neocortex, hippocampus, and amygdala perform poorly in tasks of spatial, olfactory, and taste aversion learning (Meiri et al., 1994).

Serine proteases with a role in the nervous system may be regulated by serine protease inhibitors in a manner analogous to the serine proteases involved in blood coagulation, fibrinolysis, or remodeling of non-neural tissues. One major class of inhibitors comprises structurally homologous proteins, termed serpins, which exert their inhibitory activity by forming stable complexes with their target proteases (for review, see Schapira and Patson, 1991; Potempa et al., 1994). A well characterized neurally expressed serpin is protease nexin-1 (PN-1). Initially described as a glia-derived serpin, it is also expressed by subsets of neurons (Mansuy et al., 1993). PN-1 has a neurite outgrowth-promoting effect on neuroblastoma cells and sympathetic neurons in vitro (Guenther et al., 1985; Gloor et al., 1986) that depends on its inhibitory activity toward thrombin (Gurwitz and Cunningham, 1990). We have recently identified neuroserpin, a novel serpin (Osterwalder et al., 1996), that had originally been characterized as a protein secreted from neurites of chicken embryonic dorsal root ganglion (DRG) neurons (Stoeckli et al., 1989). An analysis of its primary structure suggested that neuroserpin is an inhibitor of trypsin-like serine proteases such as thrombin and PAs. We have now isolated the cDNA of the murine homolog of neuroserpin and analyzed its spatio-temporal expression in the mouse nervous system to obtain an indication about its functional role in the developing and the adult nervous systems. To investigate the inhibitory activity and specificity of neuroserpin, we performed 
complex formation and inhibition assays with the purified recombinant protein and several neurally expressed serine proteases.

\section{MATERIALS AND METHODS}

cDNA cloning and sequencing. Total RNA from brains of postnatal day 10 (P10) mice was isolated as described by Chomczynski and Sacchi (1987). cDNA was prepared using SuperScript RNase H reverse transcriptase (Life Technologies, Gaithersburg, MD) as recommended by the manufacturer. PCR was performed with Taq polymerase (Perkin-Elmer, Branchburg, NJ) according to the supplier's recommendations. A first amplification $\left(35\right.$ cycles, $1 \mathrm{~min}$ at $93^{\circ} \mathrm{C}, 1 \mathrm{~min}$ at $50^{\circ} \mathrm{C}$, and $2 \mathrm{~min}$ at $70^{\circ} \mathrm{C}$ ) was performed with the degenerate primers $5^{\prime}$-GCI ATI TAY TTY AAR GGI AAY TGG AA-3' (sense; $\mathrm{I}=$ inosine; $\mathrm{R}=\mathrm{A}$ or $\mathrm{G}$, and $\mathrm{Y}=$ $\mathrm{T}$ or C) and 5'-CC CAT RAA IAR IAC IGT ICC NGT-3' (antisense; $\mathrm{N}=\mathrm{A}, \mathrm{G}, \mathrm{C}$, or $\mathrm{T}$ ); a fraction of the reaction products was reamplified ( 35 cycles, $1 \mathrm{~min}$ at $93^{\circ} \mathrm{C}, 1 \mathrm{~min}$ at $55^{\circ} \mathrm{C}$, and $2 \mathrm{~min}$ at $72^{\circ} \mathrm{C}$ ) with the oligonucleotides $5^{\prime}$-ggg gga tcc GAR ACI GAR GTI CAR ATI CCI ATG ATG-3' (sense) and 5'-ggg gatc cGG RTG RTC IAC IAT IAC YTG NGG-3' (antisense). The amplified $420 \mathrm{bp}$ cDNA fragment of mouse neuroserpin was labeled with $\left[\alpha^{-32} \mathrm{P}\right] \mathrm{dCTP}$ by random priming (random priming kit from Stratagene, La Jolla, CA). The labeled probe was used to screen $\sim 2 \times 10^{6}$ phage plaques of an oligo(dT)-primed P20 mouse brain cDNA library (Stratagene, catalog \#937319) as described by Sambrook et al. (1989). DNA of positive phage clones was isolated and subjected to restriction analysis. The cDNA of one of the clones with the longest cDNA insert was selected for sequencing of both strands. Sequence assembly and comparison were performed using computer programs of the Genetics Computer Group (Madison, WI) package.

Synthesis of riboprobes for Northern and in situ hybridization. As template for riboprobe synthesis, the full-length cDNA of mouse neuroserpin or fragments of it [nucleotides (nt) 1-365, 464-788, 788-1211, and 2037-2395] in the phagemid vector pBluescript (Stratagene) were linearized with restriction enzymes cutting immediately downstream of the cDNA to be transcribed. Using T3 or T7 RNA polymerase and a ribonucleotide mix containing digoxigenin-labeled uridine triphosphate (Boehringer Mannheim, Mannheim, Germany), cRNA was transcribed according to the manufacturer's recommendations. For in situ hybridization with riboprobes transcribed from the full-length cDNA, the cRNA was subjected to limited alkaline hydrolysis in $100 \mathrm{~mm}$ sodium carbonate, $\mathrm{pH} 10.2$, at $60^{\circ} \mathrm{C}$ for $40 \mathrm{~min}$. The integrity of the riboprobes was controlled by agarose gel electrophoresis, and their approximate concentration was estimated.

Northern blot analysis. Total RNA was isolated from various tissues of adult mice of strain ICR by acid guanidinium thiocyanate-phenolchloroform extraction (Chomczynski and Sacchi, 1987). Samples of $15 \mu \mathrm{g}$ of total RNA were separated on a formaldehyde-containing agarose gel, transferred to a nylon membrane, and immobilized as described by Sambrook et al. (1989). After prehybridization in hybridization buffer containing $5 \times$ SSC, $50 \%$ formamide, $0.02 \%$ SDS, $0.1 \% \quad \mathrm{~N}$ lauroylsarcosine, and $2 \%(\mathrm{w} / \mathrm{v})$ blocking reagent (Boehringer Mannheim), membranes were incubated overnight with $\sim 20 \mathrm{ng} / \mathrm{ml}$ digoxigenin-labeled RNA in hybridization buffer at $68^{\circ} \mathrm{C}$. Membranes were washed in $2 \times \mathrm{SSC} / 0.1 \%$ SDS and $0.1 \times \mathrm{SSC} / 0.1 \% \mathrm{SDS}$ at $68^{\circ} \mathrm{C}$ and incubated with an alkaline phosphatase (AP)-conjugated antidigoxigenin antibody (Boehringer Mannheim). The washed membranes were then incubated with the chemiluminescent AP substrate CDP-Star (Boehringer Mannheim) according to the supplier's recommendations and exposed to x-ray film.

In situ hybridization. In situ hybridization was performed essentially as described by Schaeren-Wiemers and Gerfin-Moser (1993). Briefly, tissues were quickly removed from ICR mice killed by asphyxiation with $\mathrm{CO}_{2}$ and immediately frozen in a bed of pulverized dry ice. To obtain mouse embryos of determined gestational age, the onset of pregnancy was determined by the appearance of a vaginal plug and counted as embryonic day 0 (E0). Embryos were checked for correct gestational age using the criteria established by Theiler (1989). For postnatal mice, the day of birth was taken as $\mathrm{P} 0$. Cryosections were cut at $12-20 \mu \mathrm{m}$ and thawmounted on poly-L-lysine-coated slides, fixed in PBS containing $4 \%$ paraformaldehyde, and acetylated with acetic anhydride. After prehybridization in hybridization buffer containing $5 \times$ SSC, $50 \%$ formamide, $5 \times$ Denhardt's solution, $250 \mu \mathrm{g} / \mathrm{ml}$ total yeast RNA, and $500 \mu \mathrm{g} / \mathrm{ml}$ DNA from herring sperm, hybridization was performed at $55^{\circ} \mathrm{C}$ overnight using $\sim 0.25 \mu \mathrm{g} / \mathrm{ml}$ digoxigenin-labeled riboprobes diluted in hybridization buffer. Sections were then subjected to low-stringency $(2 \times$ SSC) and high-stringency $\left(0.1 \times \mathrm{SSC} / 50 \%\right.$ formamide at $\left.55^{\circ} \mathrm{C}\right)$ washes. Hybridized riboprobe was detected using an AP-coupled anti-digoxigenin antibody (Boehringer Mannheim) and the AP substrates nitrotetrazolium blue and X-phosphate (Boehringer Mannheim). As a control for the specificity of the labeling, in each hybridization experiment sections adjacent to those hybridized with the antisense neuroserpin cRNA were incubated with an equal concentration of a sense riboprobe transcribed from the same template. Control sections showed no staining except for strong labeling in the intestinal mucosa of embryos older than E15, which was probably caused by endogeneous intestinal AP. In addition, we have performed in situ hybridization with four different antisense riboprobes from nonoverlapping regions of the mouse neuroserpin cDNA (nt 1-365, 464-788, 788-1211, and 2037-2395). The staining obtained with these riboprobes was qualitatively identical to that obtained with the antisense riboprobe transcribed from the full-length cDNA, which was chosen for hybridization of all sections shown in the figures.

Detection of neuroserpin in tissue extracts. For detection of neuroserpin protein in tissue extracts, neuroserpin was immunoprecipitated with the monoclonal antibody A15F2 raised against neuroserpin. The immunoprecipitate was subjected to SDS-PAGE and blotted onto nitrocellulose, and neuroserpin was detected with rabbit anti-neuroserpin antiserum. The monoclonal antibody A15F2 was obtained by immunization of a rat with recombinant mouse neuroserpin and subsequent fusion of splenic $B$ cells with the mouse myeloma cell line Ag8-653. Fusion and subsequent selection of myeloma clones were essentially performed as described by Fazekas de St. Groth and Scheidegger (1980). The antiserum R61 was raised by immunization of a rabbit with recombinant chicken neuroserpin. Tissue extracts were prepared as follows. Tissues were quickly removed from killed animals and homogenized in a buffer $(1 \mathrm{ml} / 100 \mathrm{mg}$ of tissue) containing $140 \mathrm{~mm} \mathrm{NaCl}, 10 \mathrm{~mm}$ Tris-Cl, $\mathrm{pH} \mathrm{8.0,1 \% (v/v)}$ Triton X-100, $2 \mu \mathrm{g} / \mathrm{ml}$ aprotinin, $1 \mathrm{~mm}$ iodacetamide, and $1 \mathrm{~mm}$ PMSF. Tissue extracts were cleared from insoluble material by ultracentrifugation and preincubated with Sepharose 4B (Pharmacia, Uppsala, Sweden) for at least $3 \mathrm{hr}$ at $4^{\circ} \mathrm{C}$. For immunoprecipitation, the monoclonal antibody $\mathrm{A} 15 \mathrm{~F} 2$ was purified from conditioned media by protein $\mathrm{G}$ chromatography and coupled to cyanogen bromide-activated Sepharose (A15F2S4B) at a concentration of $5 \mathrm{mg} / \mathrm{ml}$ of resin. Neuroserpin was immunoprecipitated from extracts by addition of $25 \mu \mathrm{l}$ of A15F2-S4B/ml of extract and subsequent incubation of the suspension for $3 \mathrm{hr}$ at $4^{\circ} \mathrm{C}$ on an end-over-end shaker. The A15F2-S4B slurry was washed extensively with a buffer containing $140 \mathrm{~mm} \mathrm{NaCl}, 10 \mathrm{~mm}$ Tris-Cl, $\mathrm{pH} 8.0,0.1 \%(\mathrm{v} / \mathrm{v})$ Triton X-100, and, in a last washing step, $50 \mathrm{~mm}$ Tris-Cl, $\mathrm{pH} 6.8$. Neuroserpin was eluted by boiling the affinity resin for $10 \mathrm{~min}$ in $15 \%$ $(\mathrm{v} / \mathrm{v})$ glycerol, $3 \%(\mathrm{w} / \mathrm{v})$ SDS, $60 \mathrm{~mm}$ Tris-Cl, $\mathrm{pH} 6.8$, and $0.01 \%(\mathrm{w} / \mathrm{v})$ bromphenol blue. After removal of the resin, $\beta$-Mercaptoethanol was added to the eluates to a concentration of $5 \%(\mathrm{v} / \mathrm{v})$. Samples were again boiled for $3 \mathrm{~min}$, subjected to SDS-PAGE, and blotted to nitrocellulose. Immunodetection with affinity-purified R61 antiserum, horseradish peroxidase-coupled anti-rabbit IgG polyclonal antibody, and chemiluminescent visualization was performed as recommended by the supplier of the chemiluminescence blotting kit (Boehringer Mannheim).

Heterologous expression and purification of recombinant mouse neuroserpin. Mouse neuroserpin was cytoplasmically expressed in Escherichia coli with a stretch of six histidines fused to the $\mathrm{C}$ terminus of the protein. Briefly, a fragment of mouse neuroserpin cDNA encoding amino acids 17-410 of mouse neuroserpin was amplified in a PCR using the oligodeoxynucleotides 5'-GC TCT AGA CAT ATG ACA GGG GCA ACG TTC CCA-3' and 5'-GGG AAG CTT CTA GTG GTG ATG GTG GTG GTG AAG TTC CTC AAA GTC ATG GC-3' as primers. Integrity of the amplified sequence was confirmed by DNA sequencing. The cDNA fragment was cloned into the vector pAK400 (Krebber et al., 1997) via the NdeI and HindIII sites of the vector, allowing expression of the cDNA from the lac operator/promoter located immediately upstream. For expression, a colony of $E$. coli strain $\mathrm{DH} 5 \alpha$ harboring the expression plasmid was precultured overnight at $25^{\circ} \mathrm{C}$ in $10 \mathrm{ml}$ of Luria-Bertani medium (LB) containing $25 \mu \mathrm{g} / \mathrm{ml}$ chloramphenicol. One liter of LB containing $25 \mu \mathrm{g} / \mathrm{ml}$ chloramphenicol was inoculated with the preculture, grown in a shaking water bath at $25^{\circ} \mathrm{C}$, and induced with $1 \mathrm{~mm}$ isopropyl1-thio- $\beta$-D-galactopyranoside at an $\mathrm{OD}_{600}$ of 0.5 . Bacteria were harvested by centrifugation $5 \mathrm{hr}$ after induction, resuspended in loading buffer $(1 \mathrm{M}$ $\mathrm{NaCl}$ and $50 \mathrm{~mm}$ Tris-Cl, $\mathrm{pH} 8.0$ ), and disrupted in a French press. The soluble protein extract was cleared from debris by centrifugation and loaded onto Ni-nitrilo-triacetate resin (Qiagen, Chatsworth, CA). After extensive washing with loading buffer, proteins adhering to the metal chelate resin were eluted with loading buffer containing $200 \mathrm{~mm}$ imida- 
Figure 1. Nucleotide and deduced amino acid sequence of mouse neuroserpin (EMBL and GenBank accession number AJ001700). Amino acids conserved between mouse, human, and chicken neuroserpin are printed in bold. The stop codons flanking the single large open reading frame are marked by asterisks. The putative preprotein sequence determined according to von Heijne (1983) is underlined, and putative N-glycosylation sites are emphasized with circles. The putative reactive site loop is marked by a broken line, and the residues flanking the putative reactive site are indicated according to the nomenclature of Schechter and Berger (1967) with P1 and P1'. The 3' untranslated region contains two polyadenylation signals (boxed).

zole. The eluted protein was dialyzed against $150 \mathrm{~mm} \mathrm{NaCl}$ and $10 \mathrm{~mm}$ sodium phosphate, $\mathrm{pH} 7.0$, and stored at $-80^{\circ} \mathrm{C}$.

Complex formation assay. Recombinant neuroserpin at a concentration of $1 \mu \mathrm{M}$ was incubated with recombinant human tPA (Genentech, South San Francisco, CA), uPA, plasmin, or thrombin (Sigma, St. Louis, MO) at a concentration of 0.3 or $1 \mu \mathrm{M}$ in $150 \mathrm{~mm} \mathrm{NaCl}$ and $10 \mathrm{~mm}$ sodium phosphate, $\mathrm{pH} 7.0$, for $10 \mathrm{~min}$ on ice. Ten microliters of the samples were mixed with an equal volume of SDS-PAGE loading buffer $[30 \%(\mathrm{v} / \mathrm{v})$ glycerol, $10 \%$ (v/v) $\beta$-mercaptoethanol, $6 \%$ (w/v) SDS, $125 \mathrm{~mm}$ Tris-Cl $\mathrm{pH} 6.8$, and $0.01 \%(\mathrm{w} / \mathrm{v})$ bromphenol blue] and subjected to SDS-PAGE. Neuroserpin and neuroserpin-containing protein complexes were detected by immunoblotting as described above using the antiserum R61.

Inhibition of protease amidolytic activity. tPA, uPA, plasmin, or thrombin at a concentration of $8 \mathrm{nM}$ and recombinant neuroserpin at a concentration of $26.7,80,267$, or $800 \mathrm{~nm}$ were preincubated for $5 \mathrm{~min}$ at $25^{\circ} \mathrm{C}$ in amidolytic assay buffer [ $137 \mathrm{~mm} \mathrm{NaCl}, 2.7 \mathrm{mM} \mathrm{KCl}, 4.3 \mathrm{mM} \mathrm{Na}_{2} \mathrm{HPO}_{4}$, $1.4 \mathrm{mM} \mathrm{KH}_{2} \mathrm{PO}_{4}, 0.2 \%(\mathrm{w} / \mathrm{v}) \mathrm{BSA}$, and $0.1 \%(\mathrm{w} / \mathrm{v})$ polyethylene glycol 8000]. The broad-spectrum chromogenic protease substrate $H$-D-
isoleucyl-L-prolyl-L-arginine- $p$-nitroaniline-dihydrochloride (Chromogenix, Mölndal, Sweden) was then added to a concentration of $1 \mathrm{~mm}$. Samples were further incubated at $25^{\circ} \mathrm{C}$, and the velocities of amidolytic liberation of $p$-nitroaniline were determined by measuring the absorbance at $405 \mathrm{~nm}$ at different times of the reaction.

\section{RESULTS}

\section{Cloning and characterization of the cDNA of mouse neuroserpin}

The cDNA of mouse neuroserpin was isolated by nested PCR using cDNA derived from total brain RNA and degenerate oligonucleotide primers designed on the basis of the chicken neuroserpin cDNA sequence (Osterwalder et al., 1996). The amplified $420 \mathrm{bp}$ cDNA fragment was subsequently used to screen an oligo-dT-primed postnatal mouse brain cDNA library. All posi- 


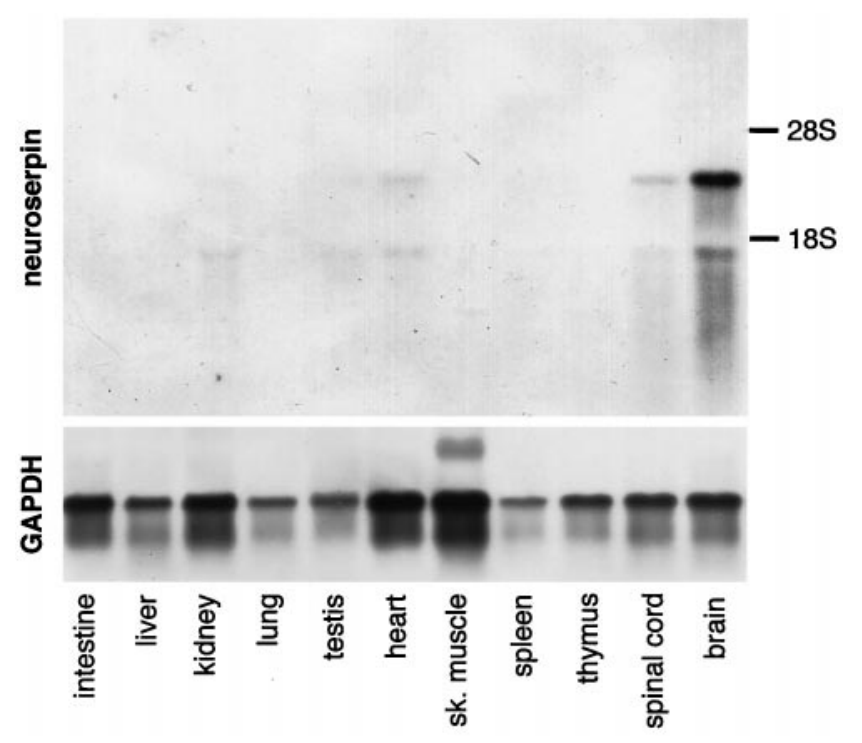

Figure 2. Distribution of neuroserpin mRNA in adult mouse tissues. Ten micrograms each of total RNA from various tissues were separated by agarose gel electrophoresis and blotted onto a nylon membrane, which was subsequently incubated with a neuroserpin antisense cRNA probe (top) or, to assess integrity of RNA, with a glyceraldehyde-3-phosphate dehydrogenase antisense riboprobe. Two neuroserpin transcripts of 1.6 and $3.0 \mathrm{~kb}$, respectively, were detected in brain and, in lower quantities, in spinal cord and heart. Testis and kidney RNA contained only the small transcript in very low amounts.

tive clones isolated and subjected to restriction analysis contained the same cDNA, either in full length of $2.9 \mathrm{~kb}$ or fragments thereof. The cDNA obtained comprised a single long ORF encoding a protein of 410 amino acids (Fig. 1). The nucleotide sequence adjacent to the putative start codon matches the consensus described by Kozak (1987). A segment of 16 amino acids after the putative translation start is rich in hydrophobic residues and conforms to the characteristics of signal peptides (von Heijne, 1985). The deduced amino acid sequence exhibits an identity of $76 \%$ to chicken neuroserpin and $86 \%$ to the recently characterized human neuroserpin (Schrimpf et al., 1997). Interestingly, the reactive site loop, a peptide segment close to the $\mathrm{C}$ terminus that interacts with the active site of the cognate protease, is fully conserved between chicken and mouse neuroserpin and shows only one conservative amino acid exchange (Ala-345 to Val) in the human species homolog. Of other known mouse serpins, PN-1 (36\% amino acid identity), antithrombin-III (34\%), and plasminogen activator inhibitor-1 $(33 \%)$ display the strongest sequence similarity to neuroserpin.

\section{Localization of neuroserpin expression in the adult mouse CNS}

The tissue distribution of neuroserpin mRNA in the adult mouse was investigated by Northern blot analysis. Two neuroserpin transcripts of $\sim 3.0$ and $1.6 \mathrm{~kb}$ were present in the brain and, in considerably smaller quantities, in the spinal cord, heart, kidney, and testis. No neuroserpin mRNA was detected in the intestine, liver, lung, skeletal muscle, spleen, and thymus (Fig. 2). The size of the two neuroserpin mRNA species may be attributed to the alternative usage of the two polyadenylation signals found at $\mathrm{nt}$ 1551-1556 and 2905-2910, respectively (Fig. 1).

The distribution of neuroserpin mRNA in the adult mouse brain was analyzed by in situ hybridization of coronal and hori- zontal brain sections (Fig. 3, Table 1). Restriction of the hybridization signals to gray matter, the size and morphology of the cells stained, and the clear delineation of the hybridization signals along the boundaries of nuclei and laminae indicated that neuroserpin in the adult brain is expressed predominantly by neurons. The most prominent expression of neuroserpin was observed in the olfactory bulb, the isocortex, the hippocampal formation, and the amygdala. In contrast, no neuroserpin transcript could be detected in the caudate putamen and in most thalamic nuclei, including all sensory relay nuclei. Neuroserpin mRNA expression was also observed in many midbrain, pontine, and medullary regions, including the superior and inferior colliculus, all motor and sensory cranial nerve nuclei, and components of the reticular formation. In the cerebellum, neurons of the deep nuclei, cells in the molecular layer, possibly basket and stellate neurons, and a few scattered cells in the granule cell layer expressed neuroserpin mRNA at moderate concentrations (see Figs. $3 H, J, 6 H$ ). In contrast, no expression was observed in granule cells or the cerebellar white matter. Moderately stained cells within or closely associated with the Purkinje cell layer but with cell bodies too small to account for Purkinje cells may resemble basket neurons or Golgi epithelial cells (see Fig. 6H). Most Purkinje cells appeared to be devoid of detectable neuroserpin expression. However, among the more numerous moderately positive smaller cells a few large, pear-shaped, weakly labeled neurons were observed, which may represent a subpopulation of Purkinje cells expressing low amounts of neuroserpin. In the spinal cord, cells with low to moderate neuroserpin expression were found in the ventral horn, the intermediate zone, and the ventral laminae of the dorsal horn (see Fig. 7G). It is noteworthy that neither the neuroserpinpositive populations of CNS neurons nor those that do not express neuroserpin mRNA can be assigned to a distinct neuronal category. Both local inhibitory (e.g., cerebellar basket and stellate cells and hippocampal interneurons) and excitatory projection neurons (e.g., pyramidal neurons of the hippocampus and spinal cord motoneurons) express neuroserpin. Likewise, many neurons with modulatory actions, such as noradregenic neurons of the locus coeruleus and serotonergic neurons of the raphe nuclei, are strongly positive for neuroserpin.

\section{Spatio-temporal pattern of neuroserpin expression in the developing nervous system}

During embryonic development, neuroserpin was predominantly expressed in the nervous system (Fig. 4). Only at very early embryonic stages (E14 and earlier) were faint hybridization signals also observed in the liver. In the PNS, DRGs, cranial nerve ganglia, both sympathetic and parasympathetic ganglia, and the olfactory epithelium expressed neuroserpin. In DRG neurons neuroserpin mRNA was observed as early as E10, and expression reached maximal levels perinatally and remained high in the adult (see Fig. 7).

Most CNS regions expressed neuroserpin during embryonic development. No expression of neuroserpin was found in periventricular neuroepithelia. Subventricular zones in most CNS regions, however, were positive for neuroserpin mRNA immediately at their appearance (Fig. 4A), suggesting that most CNS neurons start to express neuroserpin when they become postmitotic and migrate away from the ventricular zone. Neuroserpin mRNA was initially expressed rather homogeneously in low amounts throughout most CNS differentiating fields but showed a more differential distribution at later stages (E15 and older) with 

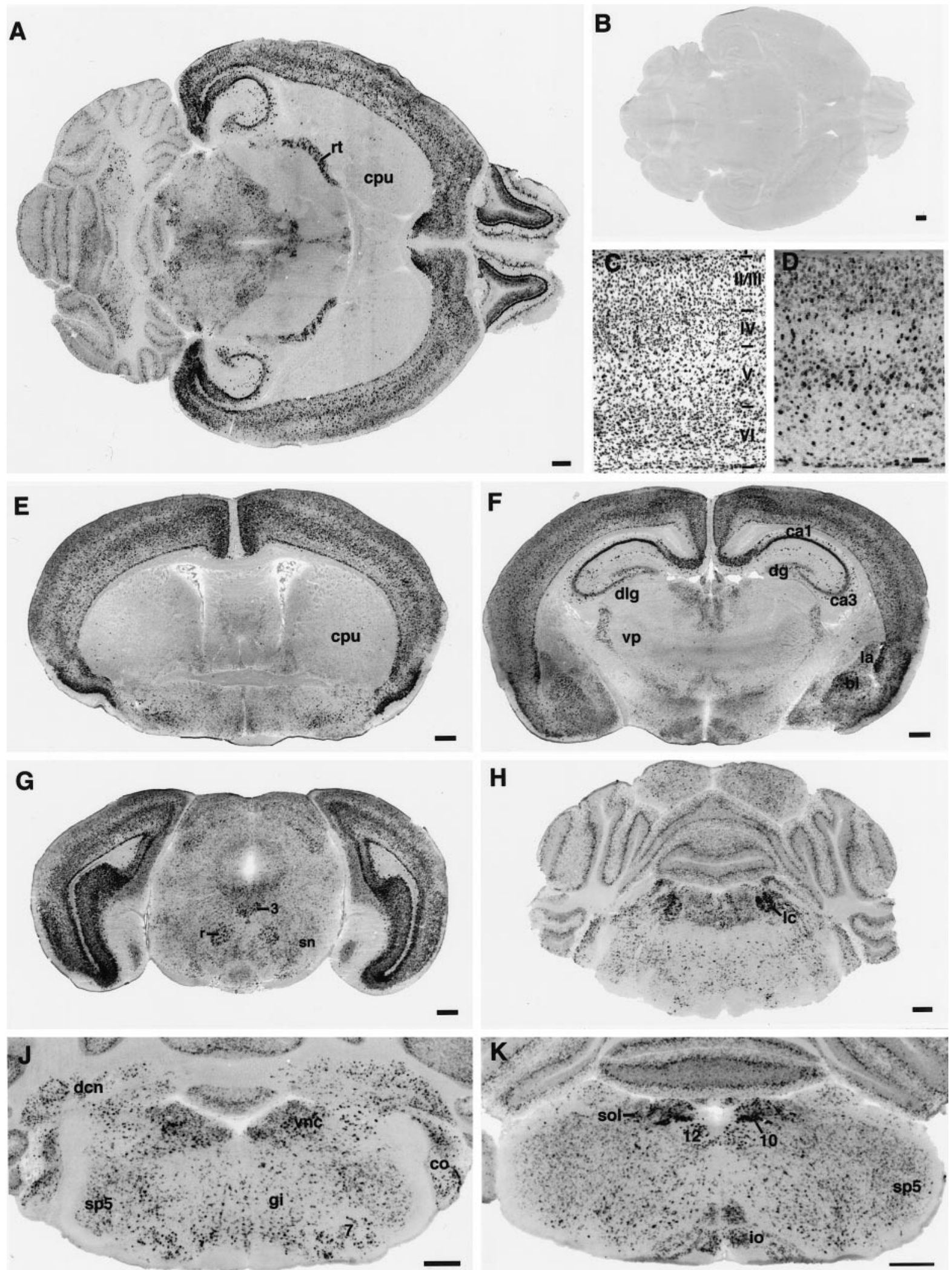

Figure 3. Neuroserpin expression in the adult mouse brain. In situ hybridization of horizontal $(A, B)$ and coronal brain sections $(E-K)$ with an antisense $(A, D-K)$ or sense riboprobe $(B)$ transcribed from the mouse neuroserpin cDNA. $C$, $D$, Consecutive coronal sections of the parietal cortex stained either with cresyl violet $(C)$ or with antisense neuroserpin mRNA $(D) .3,7,10,12$, Nuclei of the respective cranial nerves; $I, I I / I I I, I V, V, V I$, isocortical layers; $b l$, basolateral nucleus of the amygdala; cal, ca3, hippocampal fields; co, cochlear nuclei; $c p u$, caudate putamen; dcn, deep cerebellar nuclei; $d l g$, dorsal lateral geniculate nucleus; $d g$, dentate gyrus; $g i$, gigantocellular reticular nucleus; io, inferior olive; $l a$, lateral nucleus of the amygdala; $l c$, locus coeruleus; $r$, red nucleus; $r t$, reticular thalamic nucleus; $s n$, substantia nigra; sol, solitary nucleus; $s p 5$, spinal trigeminal nucleus; $v n c$, vestibular nuclear group; $v p$, ventroposterior thalamic nucleus. Scale bars: $A, B, E-K, 500 \mu \mathrm{m} ; D, 100 \mu \mathrm{m}$. 


\begin{tabular}{|c|c|c|c|c|c|}
\hline Isocortex & & Septum & & Pretectal nu group & ++ \\
\hline Layer I & $0 /++^{a}$ & Medial septal nu & + & & \\
\hline Layer II-III & $++/+++$ & $\mathrm{Nu}$ diagonal band (Broca) & + & Superior colliculus & $+/++$ \\
\hline Layer IV & $0 /+++{ }^{b}$ & Lateral septal nu & 0 & & \\
\hline Layer V & +++ & & & Inferior colliculus & + \\
\hline \multirow[t]{2}{*}{ Layer VI } & $+/+++$ & Hypothalamus & & & \\
\hline & & Periventricular preoptic nu & + & Central gray & $+/++$ \\
\hline Cingulate cortex & +++ & Medial preoptic nu & + & Dorsal tegmental nu & +++ \\
\hline Piriform cortex & +++ & Magnocellular preoptic nu & ++ & & \\
\hline \multirow[t]{2}{*}{ Entorhinal cortex (s. II-VI) } & +++ & Suprachiasmatic nu & 0 & Cranial nerve nuclei & \\
\hline & & Paraventricular nu & ++ & Oculomotor nu & ++ \\
\hline \multirow[t]{2}{*}{ Subiculum (s. pyramidale) } & +++ & Anterior hypothalamic nu & + & Trochlear nu & ++ \\
\hline & & Supraoptic nu & ++ & Motor trigeminal nu & ++ \\
\hline Hippocampus & & Arcuate nu & + & Principal sensory trigem. nu & ++ \\
\hline S. pyramidale, CA1 & +++ & Ventromedial nu & + & Abducens nu & ++ \\
\hline S. pyramidale, CA $2 / 3$ & $+/+++^{c}$ & Dorsomedial nu & + & Facial nu & ++ \\
\hline CA4 & +++ & Tuberal nu & + & Vestibular nu group & ++ \\
\hline Dentate granule cell layer & $+/+++^{a}$ & Medial mammillary nu & & Cochlear nu group & ++ \\
\hline S. oriens & $+++^{c}$ & Medial subnucleus & +++ & Dorsal motor nu of vagus & +++ \\
\hline S. lucidum & $+++^{c}$ & Lateral subnucleus & 0 & Hypoglossal nu & ++ \\
\hline S. radiatum & $+++^{c}$ & Lateral mammillary nu & + & $\mathrm{Nu}$ of the solitary tract & ++ \\
\hline \multirow[t]{2}{*}{ S. moleculare/lacunosum mol. } & 0 & & & & \\
\hline & & Epithalamus & & Red nu & ++ \\
\hline Olfactory bulb & & Medial habenular nu & + & & \\
\hline Olfactory nerve layer & 0 & Lateral habenular nu & 0 & Pontine nuclei & 0 \\
\hline Glomerular layer & $0 /++$ & & & Reticulotegmental nu pons & ++ \\
\hline Mitral cell layer & +++ & Thalamus dorsalis & & Lateral reticular nu & ++ \\
\hline Internal plexiform layer & ++ & Anterodorsal nu & + & Inferior olive & $+/++$ \\
\hline \multirow[t]{2}{*}{ Granular layer } & ++ & Anteroventral nu & 0 & & \\
\hline & & Anteromedial nu & 0 & Cerebellum & \\
\hline Amygdala & & Mediodorsal nu & 0 & Molecular layer & $++^{d}$ \\
\hline Olfactory amygdala & ++ & Laterodorsal nu & 0 & Purkinje cell layer & $0 /++^{e}$ \\
\hline Medial amygdala & ++ & Lateroposterior nu & 0 & Granule cell layer & $0 /++^{f}$ \\
\hline Basolateral amygdala & +++ & Posterior nu group & 0 & Deep cerebellar nuclei & ++ \\
\hline \multirow[t]{2}{*}{ Central amygdaloid nu } & + & Paraventricular nu & ++ & & \\
\hline & & Reuniens nu & +++ & Locus coeruleus & +++ \\
\hline Basal ganglia & & Centromedial nu & + & & \\
\hline Accumbens nu & 0 & Parafascicular nu & + & Superior olivary complex & + \\
\hline Caudate putamen & 0 & Ventromedial nu & 0 & & \\
\hline Globus pallidus & $0 /+^{a}$ & Ventrolateral nu & 0 & Dorsal raphe nu & ++ \\
\hline Entopeduncular nu & 0 & Ventroposterior nu & 0 & Raphe pontis nu & + \\
\hline Subthalamic nu & +++ & Medial geniculate nu & 0 & Gigantocellular reticular nu & ++ \\
\hline Substantia nigra & & Lateral geniculate nu & & Medullary reticular field & ++ \\
\hline Pars reticulata & + & Dorsal subdivision & 0 & & \\
\hline \multirow[t]{2}{*}{ Pars compacta } & + & Ventral subdivision & + & Gracilis nu & + \\
\hline & & Reticular nu & +++ & Cuneate nu & + \\
\hline
\end{tabular}

nu, Nucleus; s, stratum; 0 , no; + , low; ++ , moderate; +++ , strong neuroserpin expression.

${ }^{a}$ Very few cells positive for neuroserpin mRNA.

${ }^{b}$ Granule cells of layer IV not stained; some large, strongly expressing cells.

${ }^{c}$ Scattered strongly positive cells; distribution reminiscent of interneurons.

${ }^{d}$ Neuroserpin-positive cells likely represent stellate and basket interneurons as judged by number and morphology of labeled cells.

${ }^{e}$ Most Purkinje cells devoid of neuroserpin mRNA (see Results).

${ }^{f}$ Very low number of positive cells, possibly Golgi neurons.

highest levels of expression in the neocortex, the hippocampus, the cerebellar primordium, pons, and medulla (Fig. 4B,C).

In the neocortex, neuroserpin expression was observed in the emerging intermediate zone at E13 and increased at E15 (Fig. $4 B)$. At E17, neuroserpin mRNA was detected in high amounts in the infragranular part of the cortical plate and in the subplate and in lower amounts in the supragranular part of the cortical plate and in the intermediate zone (Fig. $4 E$ ). During postnatal development, levels of expression in all neocortical layers still increased to reach adult levels of expression during the second postnatal week.

Transient expression of neuroserpin during embryonic and 

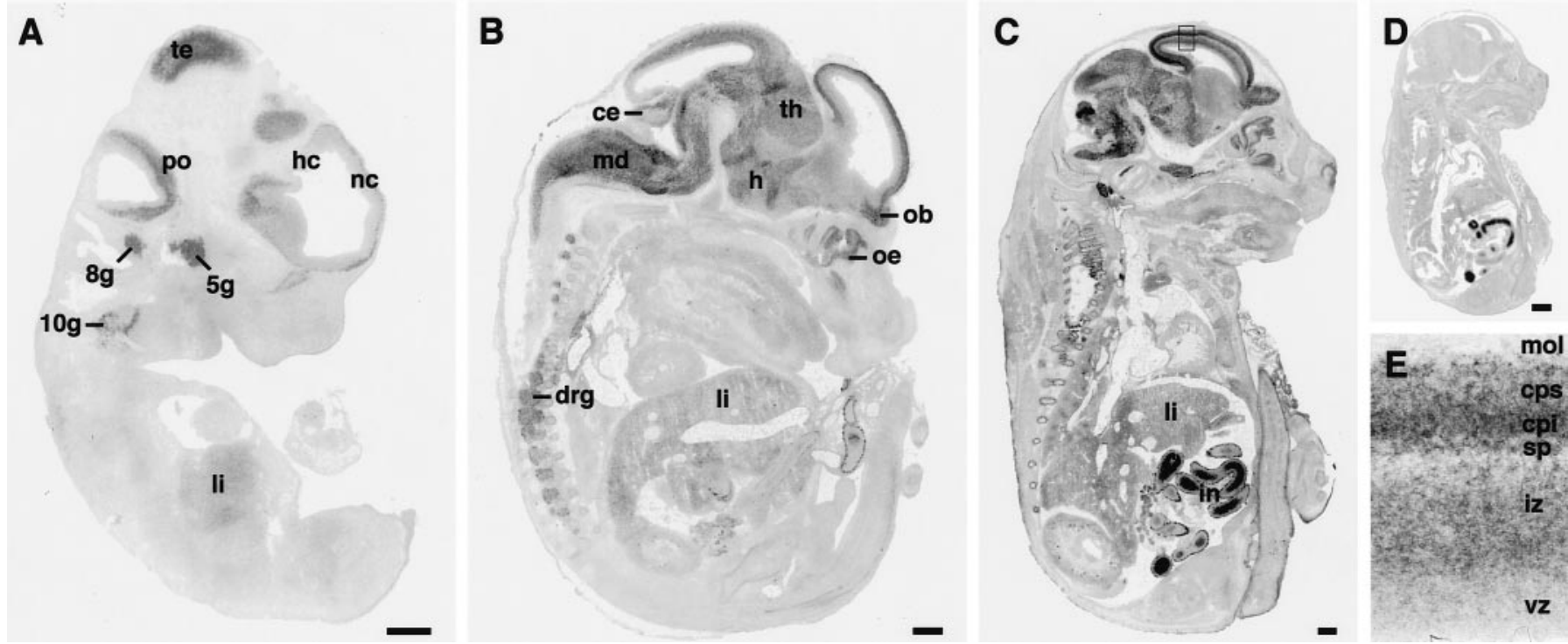

Figure 4. Distribution of neuroserpin mRNA in the developing mouse. Parasagittal sections of E13 $(A)$, E15 $(B)$, and E17 $(C, D)$ mouse embryos hybridized with a neuroserpin antisense $(A-C)$ or sense $(D)$ riboprobe. $5 g, 8 g$, $10 g$, Ganglia of fifth, eighth, and 10 th cranial nerves, respectively; $c e$, cerebellar primordium; $d r g$, dorsal root ganglia; $h$, hypothalamus; $h c$, hippocampus; in, intestine; $l i$, liver; $m d$, medulla; $n c$, neocortex; $o b$, olfactory bulb; $o e$, olfactory epithelium; $p o$, pons; te, tectum; th, thalamus. Note that staining in the intestinal mucosa in sections from E17 mice results from the presence of tissue-derived intestinal alkaline phosphatase. Cells scattered between intestinal muscle layers, however, are specifically stained in antisense sections and may represent plexus of the autonomous nervous system. E, Enlargement of a region of the E17 neocortex (boxed in $C$ ). mol, Molecular layer; cpi infragranular part of cortical plate; $c p s$, supragranular part of the cortical plate; $s p$, subplate; $i z$, intermediate zone; $v z$, ventricular zone. Scale bars: $A-C$, $500 \mu \mathrm{m} ; D, 1 \mathrm{~mm}$.

early postnatal development was observed in the thalamus (Fig. 5). Beginning at E13, i.e., before thalamic neuronal precursors have begun to extend neurites (Lund and Mustari, 1977; Altman and Bayer, 1989), and continuing throughout embryonic development, low amounts of neuroserpin mRNA were distributed rather homogeneously throughout the anterior and posterior thalamic differentiating fields. No neuroserpin expression, however, could be detected in the differentiating field of the reticular nucleus. In the reticular nucleus neuroserpin expression, first observed at P2, increased rapidly during postnatal development (Fig. 5B,C). In contrast, expression in the ventrolateral-ventromedial nuclear complex and in most thalamic association nuclei rapidly declined at approximately P4 (Fig. 5B). Likewise, neuroserpin mRNA disappeared from the sensory relay nuclei between P6 and P8 (Fig. 5E,F).

In the differentiating field of the cerebellar primordium, neuroserpin mRNA was detected in low quantities at E13 (not shown). In 15-d-old embryos, neuroserpin was expressed in low amounts both in the nuclear transitory zone, giving rise to the deep cerebellar nuclei (Altman and Bayer, 1985a), and in the cortical transitory zone (Fig. 6A). Between E17 and E19 clusters of cells that express neuroserpin very strongly became apparent in the differentiating fields of the cerebellar hemispheres (Fig. 6B). These cells may represent Purkinje cells migrating radially from the lateral cerebellar primordium to a superficial position beneath the external germinal layer (EGL) of the cerebellar hemispheres (Altman and Bayer, 1985b). In contrast, the already settled Purkinje cells of the posterior vermis expressed no or very small amounts of neuroserpin. In the postnatal mouse cerebellum, strong expression of neuroserpin was observed in patches of Purkinje cells that appeared to be confined to parts of the cerebellar hemispheres and the lateral vermis (Fig. $6 C-E$ ); the amount of neuroserpin mRNA in these Purkinje cell clusters sharply declined between P8 and P12. Purkinje cells of the cere- bellar hemispheres outside these strongly expressing clusters contained only intermediate amounts of neuroserpin mRNA, whereas Purkinje cells of the medial vermis expressed no detectable quantities of neuroserpin during this developmental period. The EGL, devoid of neuroserpin mRNA during embryonic development, became positive for neuroserpin mRNA at approximately P2. Whereas premigratory granule cells in the EGL expressed only low amounts of transcript, higher levels of neuroserpin mRNA were observed in postmigratory granule cells in the internal granular layer during the first 2 postnatal weeks (Fig. $6 F, G$ ); expression in granule cells decreased to undetectable levels after the third postnatal week (Fig. 6H). Neuroserpinpositive cells in the molecular layer were first observed at approximately P12. Expression in these cells, probably stellate and/or basket interneurons, increased to reach adult levels by P20.

In the spinal cord, neuroserpin expression was observed as early as at E10 (Fig. 7B). In the mantle layer of the spinal cord both in the alar plate and in the basal plate, differentiating neurons expressed low amounts of neuroserpin, whereas the ventricular zone, roof plate, and floor plate were devoid of neuroserpin-expressing cells. At this stage, motoneurons in the basal plate (Wentworth, 1984a) and association neurons in the alar plate have just begun to differentiate, and axons of many commissural neurons cross the floor plate (Wentworth, 1984b). In 13-d-old embryos, the number of neuroserpin-expressing cells both in the alar and in the the basal plate had increased considerably (Fig. $7 C$ ) and by E15 only the now relatively small ventricular zone, the floor plate, and the fiber tracts were devoid of neuroserpin-positive cells (Fig. 7D). In all spinal cord regions, the level of neuroserpin expression increased steadily and reached maximal levels perinatally (Fig. $7 E$ ); thereafter, it decreased in all laminae. Whereas motoneurons reached their moderate adult expression levels by $\mathrm{P} 6$, and cells in the substantia gelatinosa ceased neuroserpin expression by this time (Fig. $7 F$ ), expression 

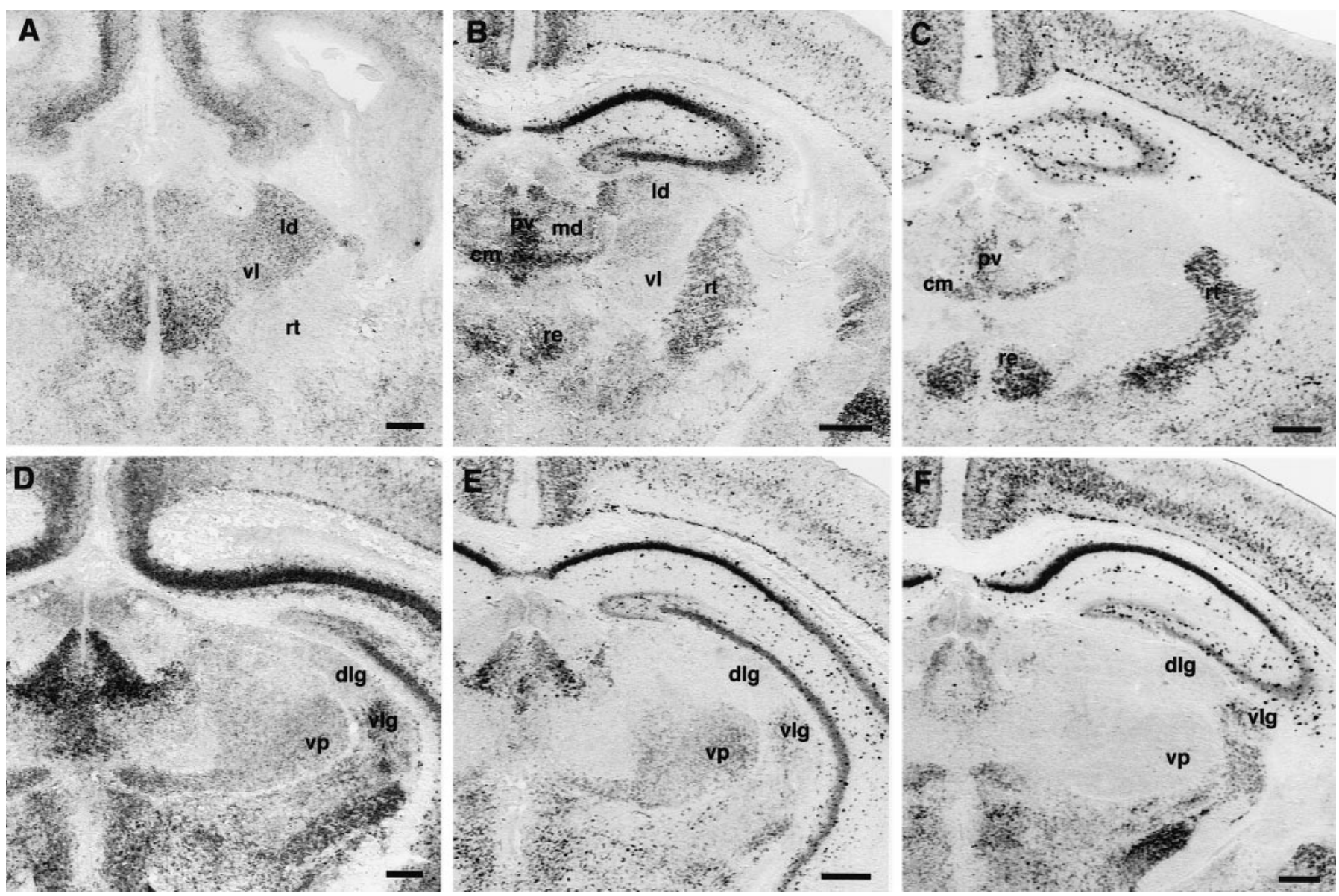

Figure 5. Neuroserpin expression in the developing thalamus. Coronal sections of the anterior $(A-C)$ or posterior $(D-F)$ thalamus of E18 $(A)$, $\mathrm{P} 0(D)$, $\mathrm{P} 4(B), \mathrm{P} 8(E)$, or $\mathrm{P} 12(C, F)$ mice; in situ hybridization using an antisense neuroserpin riboprobe. Cm, Centromedial nucleus; $d l g$, dorsal lateral geniculate nucleus; $l d$, laterodorsal nucleus; $m d$, mediodorsal nucleus; $p v$, paraventricular nucleus; $r e$, reuniens nucleus; $r t$, reticularis nucleus; $v l$, ventrolateral nucleus; $v l g$, ventral lateral geniculate nucleus; $v p$, ventroposterior nucleus. Scale bars: $A, D, 200 \mu \mathrm{m} ; B, C, E, F, 400 \mu \mathrm{m}$.

in neurons of the intermediate zone and the ventral laminae of the dorsal horn declined more slowly to reach intermediate adult quantities by the third postnatal week (Fig. 7G).

\section{Spatio-temporal distribution of neuroserpin protein}

We also investigated the distribution of neuroserpin protein both in various non-neuronal tissues and in the CNS. Because we were not able to detect neuroserpin by immunohistochemistry or in tissue extracts directly by immunoblot analysis, we immunoprecipitated neuroserpin from extracts using a rat monoclonal antibody directed against mouse neuroserpin and subjected precipitated protein to immunoblotting using an antiserum against neuroserpin raised in rabbit. In the adult mouse, neuroserpin protein was detected in the brain and spinal cord, and, in lower amounts, in testis (Fig. 8A) In most tissues, this distribution closely reflects the occurrence of neuroserpin mRNA as observed by Northern blot (Fig. 2). The failure to detect neuroserpin protein in heart and kidney, tissues shown to contain small amounts of neuroserpin mRNA, may be attributable to tissuespecific differences in the regulation of posttranscriptional processes or protein turnover. In the adult murine brain, neuroserpin was detected in the neocortex, hippocampus, olfactory bulb, and, in smaller quantities, in striatum, thalamus, and cerebellum (Fig. $8 B$ ). The occurrence of significant amounts of neuroserpin protein in striatum and thalamus, brain regions in which only small subpopulations of neurons express neuroserpin mRNA, may be indicative for an axonal transport of the protein, complementing data on axonal transport and secretion of neuroserpin in primary neuronal cultures (Stoeckli et al., 1989; Osterwalder et al., 1996). In total brain extracts of different developmental stages, the amount of neuroserpin protein was found to increase between E14 and E17, to reach a maximum perinatally, and to decline slowly thereafter to an intermediate level in the adult (Fig. $8 C$ ), arguing in favor of a function of the protein during late embryonic or postnatal development of the nervous system or its maintenance in the adult.

\section{Inhibition of plasminogen activators and plasmin, but not of thrombin, by recombinant neuroserpin in vitro}

The majority of proteins belonging to the structurally defined family of serpins are inhibitors of serine proteases, yet some serpins such as ovalbumin, angiotensinogen, and the thyroxineand corticosteroid-binding globulins do not exhibit inhibitory activity. Inhibitory serpins act as substrate mimics, forming stable stoichiometric complexes with their cognate proteases. By sequence comparison with other serpins, neuroserpin was predicted to be an inhibitory serpin directed against trypsin-like proteases (Osterwalder et al., 1996). To test this hypothesis and to determine the inhibitory specificity, we have heterologously expressed neuroserpin fused C-terminally to a stretch of six histidines in $E$. 

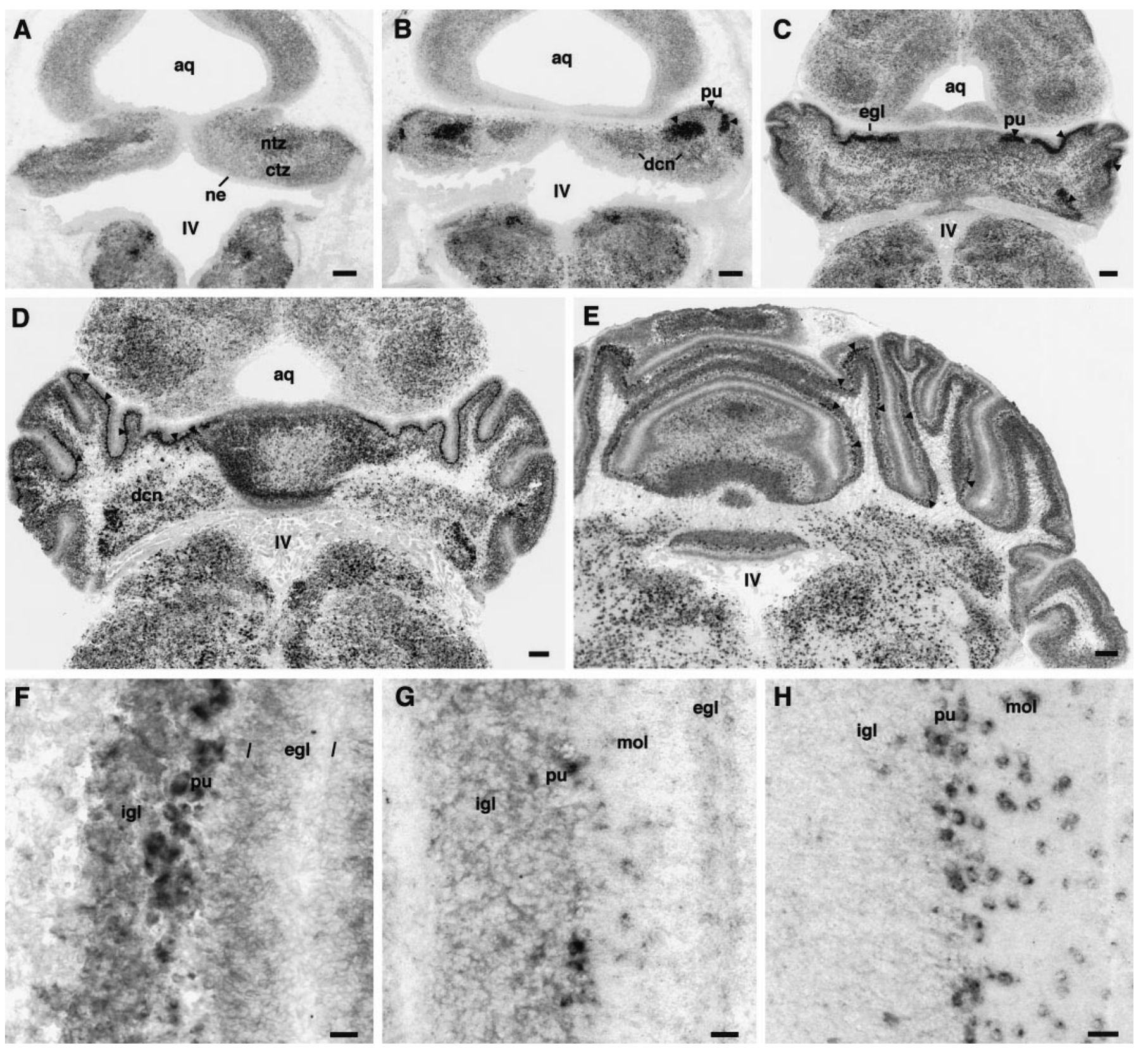

Figure 6. Detection of neuroserpin mRNA in the developing cerebellum. Coronal sections of the cerebellar primordium or cerebellum at E15 ( $A$ ), E16.5 $(B), \mathrm{P} 0(C), \mathrm{P} 4(D)$, and $\mathrm{P} 8(E)$; higher magnification of the fifth cerebellar lobule sectioned coronally at P8 $(F), \mathrm{P} 12(G)$, and $\mathrm{P} 28(H)$. The latter developmental stage closely resembles neuroserpin mRNA staining in the adult cerebellum. Arrowheads in $B-E$ denote patches of Purkinje cells strongly positive for neuroserpin. $I V$, Fourth ventricle; $a q$, aqueduct; $c t z$, cortical transition zone; $d c n$, deep cerebellar nuclei; egl, external germinal layer; igl, inner granular layer; $\mathrm{mol}$, molecular layer; $n e$, neuroepithelum; $n t z$, nuclear transition zone; $p u$, Purkinje cell layer. Scale bars: $A-E, 200 \mu \mathrm{m} ; F-H, 25 \mu \mathrm{m}$.

coli and purified the recombinant protein by metal chelate affinity chromatography (Fig. 9A). The inhibitory activity of recombinant mouse neuroserpin toward tPA, urokinase, plasmin, and thrombin, neurally expressed serine proteases (Dihanich et al., 1991; Dent et al., 1993; Sappino et al., 1993; Tsirka et al., 1997), was assessed. For this purpose, we tested the ability of neuroserpin to form stable complexes with these proteases, taking advantage of the fact that serine protease-serpin complexes are stable during SDS-PAGE. When recombinant neuroserpin was incubated with tPA, and the sample was analyzed by SDS-PAGE followed by immunoblotting with an antiserum against neuroserpin, two protein complexes were observed (Fig. 9B). These immunore- active protein complexes had apparent molecular weights that corresponded to the sum of the molecular weights of neuroserpin and single-chain tPA or the protease domain of twochain tPA, respectively. Similarly, when recombinant neuroserpin was incubated with urokinase or plasmin, protein complexes with apparent molecular weights corresponding to the sum of the molecular weights of neuroserpin and urokinase or plasmin, respectively, were detected. In contrast, no protein complexes containing neuroserpin were formed when recombinant neuroserpin was incubated with thrombin. In a second set of experiments, we tested the ability of recombinant neuroserpin to inhibit the amidolytic activity of tPA, urokinase, 

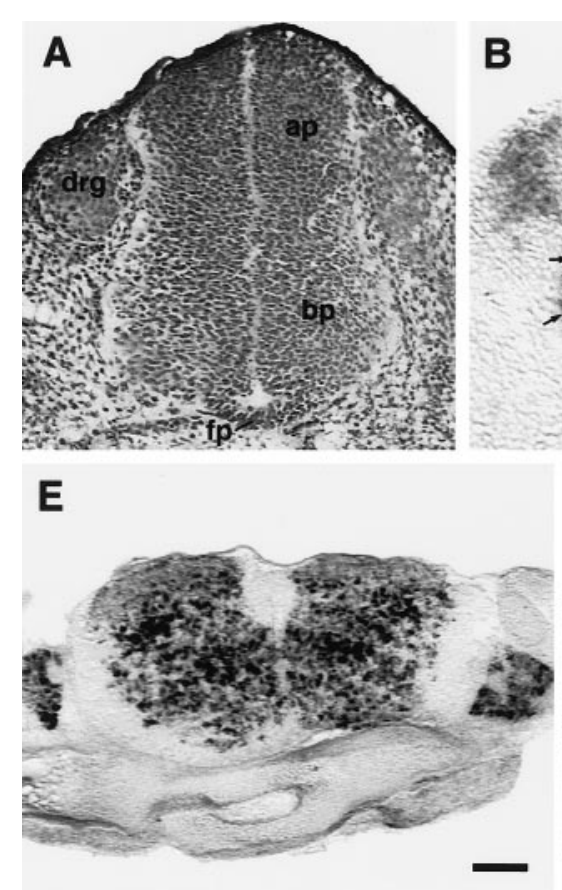
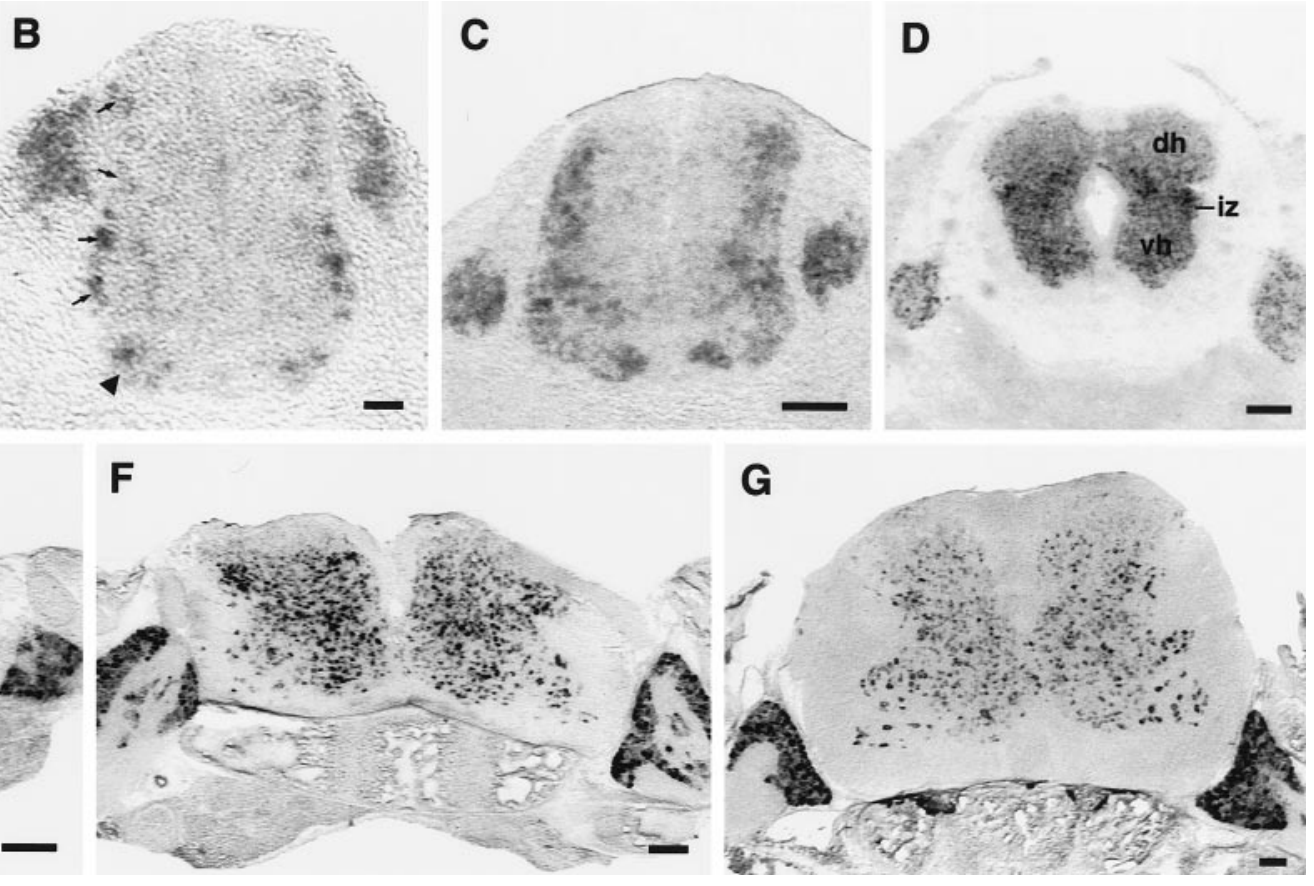

Figure 7. Neuroserpin mRNA distribution in the developing spinal cord and DRG. Transverse sections of cervical spinal cord at E10.5 $(A, B)$, E13 $(C)$, E15 $(D), \mathrm{P} 0(E), \mathrm{P} 6(F)$, and $\mathrm{P} 21(G)$. Sections shown in $B-G$ were hybridized with a neuroserpin antisense riboprobe. The section shown in $A$ is a section adjacent to that in $B$ stained with cresyl violet. The arrowhead in $B$ marks differentiating motoneurons; arrows point to commissural and/or association neurons. $a p$, Alar plate; $b p$, basal plate; $d h$, dorsal horn; $d r g$, dorsal root ganglion; $f p$, floor plate; $i z$, intermediate zone; $v h$, ventral horn. Scale bars: $B, 100 \mu \mathrm{m} ; C, D, 200 \mu \mathrm{m} ; E-G, 400 \mu \mathrm{m}$.

plasmin, and thrombin on the broad-spectrum chromogenic serine protease substrate D-isoleucyl-L-prolyl-L-arginine- $p$ nitroaniline. Recombinant neuroserpin inhibited the amidolytic activity of tPA and, to a smaller extent, uPA and plasmin, but it failed to inhibit thrombin (Fig. 9C). Essentially the same results concerning complexation and inhibition of serine proteases have been obtained with recombinant chicken neuroserpin (T. Osterwalder, P. Cinelli, A. Baici, A. Pennella, S. R. Krueger, S. P. Schrimpf, M. Meins, and P. Sonderegger, unpublished observations).

\section{DISCUSSION}

\section{Neuroserpin is expressed during neuronal migration, axon outgrowth, and synaptogenesis}

Serine proteases have been implicated in a variety of developmental processes such as neuronal migration (Seeds et al., 1990; Friedman and Seeds, 1995), neurite outgrowth (Pittman et al., 1989; Pittman and DiBenedetto, 1995), and establishment of mature synaptic connections (Hantaï et al., 1989; Liu et al., 1994). Because it is conceivable that a neuronally expressed protease inhibitor might serve as a modulator of serine protease action during nervous system development, the expression of neuroserpin was analyzed with regard to a spatiotemporal coincidence with the respective processes. Neuroserpin mRNA can be detected in neuronal precursors of most CNS regions immediately after becoming postmitotic and migrating from the ventricular zones. In the neocortex, neuronal precursors migrating to the cortical plate express neuroserpin weakly; neurons that have settled in the cortical plate and extend axons that eventually establish synaptic contacts, however, contain larger amounts of neuroserpin mRNA. In the thalamus, again, neuroserpin expression begins shortly after neurons have left the neuroepithelium. Expression then continues at approximately constant levels throughout growth of thalamocortical fibers, the formation of transient contacts between axons and subplate neurons, and the ingrowth of thalamic axons into the cortical plate perinatally. Expression of neuroserpin is downregulated in association and sensory relay nuclei of the thalamus during or shortly after the period of projection refinement by synapse elimination. In the cerebellum, neurons of the deep cerebellar nuclei are positive for neuroserpin mRNA already at the time of axon outgrowth and their translocation from the surface of the cerebellar primordium into a deeper position; they remain positive during later development. A subset of Purkinje cells in the cerebellar hemispheres becomes neuroserpin-positive during their radial migration from the neuroepithelium to the surface of the cerebellar primordium. These Purkinje cells continue to express neuroserpin strongly during the first postnatal week, when corticonuclear projections have already been established and granule cells form synaptic contacts with Purkinje cells. Granule cells synthesize low amounts of neuroserpin shortly before and higher amounts after their migration from the EGL to the internal granular layer. Expression in these neurons declines only after synaptic contacts to Purkinje cells have been established. In the spinal cord, neurons in the mantle layer of both the basal and the alar plate become positive for neuroserpin when the motoneurons and association neurons extend neurites and the axons of commissural neurons cross the floor plate. Maximal expression by motoneurons, neurons of the dorsal horn, and the intermediate zone is, however, reached during the first week of postnatal development, well after the major phase of axogenesis and during the period of synapse elimination at the neuromuscular junction. Taken to- 
A

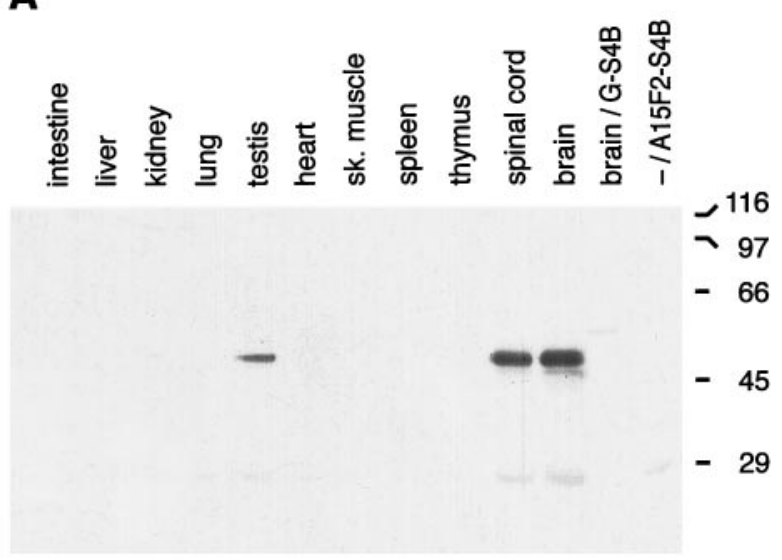

B

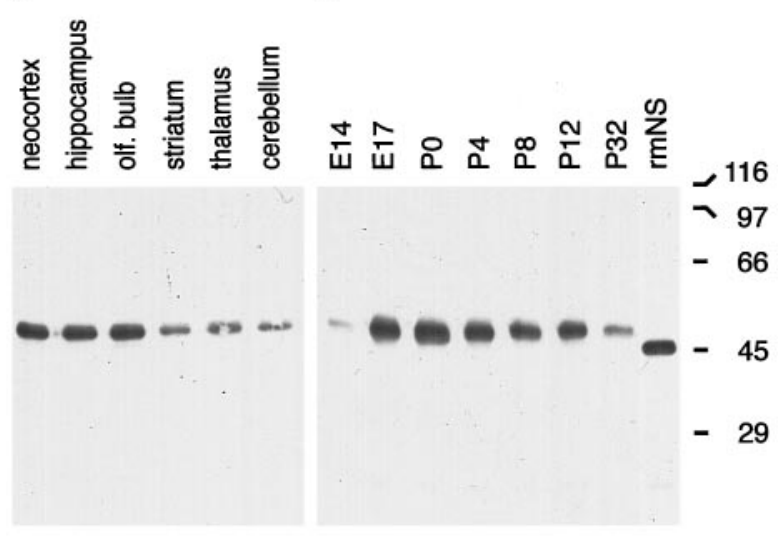

Figure 8. Detection of neuroserpin protein in tissue extracts. $A$, Neuroserpin in extracts of adult mouse tissues. Extracts were prepared from 250 $\mathrm{mg}$ of each tissue, and neuroserpin was immunoprecipitated from these extracts with the monoclonal anti-neuroserpin antibody A15F2 coupled to Sepharose 4B. Precipitated proteins were subjected to SDS-PAGE and immunoblotting using a rabbit antiserum against neuroserpin. As a control for specificity of immunodetection, a brain extract was mockprecipitated with glycine-quenched, $\mathrm{CNBr}$-activated Sepharose $4 \mathrm{~B}$ and immunoblotted (brain/G-S4B). Additionally, A15F2-coupled Sepharose incubated with homogenization buffer instead of tissue extract was mockeluted with SDS-PAGE loading buffer and subjected to Western blot analysis $(-/ A 15 F 2-S 4 B)$. Positions of molecular weight standards are indicated on the right (in kilodaltons). $B$, Neuroserpin in extracts of different brain regions. Extracts of different regions of adult mouse brains were prepared, and their total protein concentration was adjusted to $5 \mathrm{mg} / \mathrm{ml}$ From $3 \mathrm{ml}$ of these extracts, neuroserpin was immunoprecipitated and detected as described above. olf. bulb, Olfactory bulb. $C$, Neuroserpin in brain extracts of different developmental stages. Extracts from heads (E14) or total brains (others) of different developmental stages were prepared, and their total protein concentration was adjusted to $5 \mathrm{mg} / \mathrm{ml}$. From $3 \mathrm{ml}$ of these extracts, neuroserpin was immunoprecipitated and detected as described above. Thirty nanograms of recombinant mouse neuroserpin in $1 \mathrm{ml}$ of homogenization buffer were subjected to the same immunoprecipitation and immunoblotting procedure $(r m N S)$. Positions of molecular weight standards are indicated on the right (in kilodaltons).

gether, these observations indicate that neuroserpin is expressed during all developmental stages for which an involvement of plasminogen activators has been discussed. Data on temporal expression of neuroserpin argue in favor of an engagement of neuroserpin in later developmental processes, such as synaptogenesis or the refinement of synaptic connec-
A

B
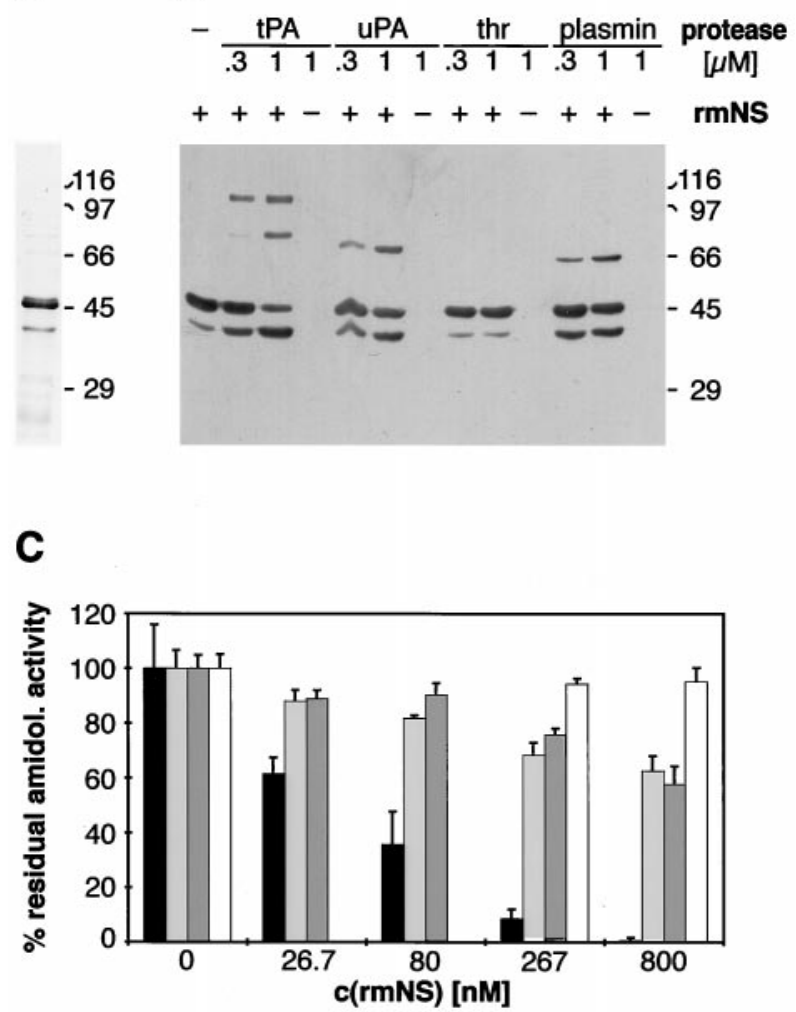

tPA

urokinase $\square$ plasmin

thrombin

Figure 9. Inhibitory specificity of neuroserpin. A, Purified recombinant mouse neuroserpin. Neuroserpin tagged $\mathrm{C}$-terminally with a stretch of six histidines was recombinantly expressed in E. coli and purified by metal chelate affinity chromatography. A representative preparation of recombinant neuroserpin subjected to SDS-PAGE is shown. Proteins were visualized by silver staining. Positions of molecular weight standards are indicated on the right (in kilodaltons). $B$, Neuroserpin forms SDS-stable complexes with tPA, uPA, and plasmin but not with thrombin. Recombinant mouse neuroserpin $(r m N S)$ at a concentration of $1 \mu \mathrm{M}$ was incubated either alone (1st lane) or together with $0.3 \mu \mathrm{M}$ or $1 \mu \mathrm{M}$ of either tPA, uPA, thrombin (thr), or plasmin (as indicated above). Samples were then subjected to SDS-PAGE under reducing conditions, and the proteins were blotted to nitrocellulose. Neuroserpin or protein complexes containing neuroserpin were detected using an antiserum raised against neuroserpin. To exclude cross-reactivity of the antiserum toward proteins in the serine protease samples, equal amounts of the respective proteases were loaded on the gel without previous addition of neuroserpin $(4 t h, 7 t h, 10 t h, 13 t h$ lanes). Positions of molecular weight standards are indicated on the right (in kilodaltons). $C$, Neuroserpin inhibits the amidolytic activity of plasminogen activators and plasmin but fails to inhibit thrombin. Serine proteases tPA, uPA, plasmin, and thrombin at a constant concentration of $8 \mathrm{nM}$ were preincubated with various concentrations of purified recombinant neuroserpin. After addition of the protease substrate D-isoleucyl-Lprolyl-L-arginine- $p$-nitroaniline samples were incubated at $25^{\circ} \mathrm{C}$, and the velocity of $p$-nitroaniline liberation was determined by measuring the extinction of the samples at $405 \mathrm{~nm}$ at different time intervals. The residual amidolytic activity of a protease in a sample containing neuroserpin was calculated as the ratio between the initial reaction velocity of this sample and the initial reaction velocity of a sample not containing neuroserpin. Experiments were performed in triplicate for every protease and concentration of neuroserpin. Error bars indicate SD.

tions: in some regions of the CNS expression of neuroserpin mRNA still increases well after the major phases of neuronal migration and axogenesis. Moreover, the maximal amounts of neuroserpin protein in the brain are reached only perinatally. 


\section{Neuroserpin may act as a regulator of tPA activity in the nervous system}

For an understanding of the function of neuroserpin in nervous system development or maintenance, it is important to determine its cognate serine protease(s). Here we show that plasminogen activators and plasmin, but not thrombin, form SDS-stable complexes and are inhibited by neuroserpin in vitro. Especially, the amidolytic activity of tPA was shown to be strongly inhibited by neuroserpin. Intriguingly, this serpin is expressed in many CNS regions that are also known to express tPA. In the adult rodent brain, tPA mRNA has been detected not only in ependyma, meninges, vascular endothelium, and glial cells in many brain regions, but also in mitral cells and granule cells of the olfactory bulb (Thewke and Seeds, 1996), in the hippocampal formation in pyramidal cells of the CA fields and granule cells of the dentate gyrus (Qian et al., 1993; Sappino et al., 1993), and in granule cells and Purkinje cells of the cerebellum (Ware et al., 1995; Seeds et al., 1995). We found neuroserpin to be expressed in the same structures, although not always by the same neuronal cell populations. It should be noted, however, that the patterns of mRNA expression do not allow the conclusion that the corresponding proteins are colocalized. Two proteins synthesized by a given neuron may be released at different sites, for example, axon terminals and dendrites; conversely, two proteins synthesized by different neurons could be colocalized at a synapse. Therefore, a decisive answer to the question of a spatio-temporal colocalization of neuroserpin and tPA will only become possible once appropriate antibodies are available for immunohistochemical localization of the proteins. Besides tPA, other neurally expressed serine proteases have to be considered as potential cognate proteases of neuroserpin; uPA and plasmin, inhibited by recombinant neuroserpin to some extent in vitro, were reported to be expressed in the murine CNS (Sumi et al., 1992; Dent et al., 1993; Tsirka et al., 1997). Other possible targets for an inhibition by neuroserpin include neuropsin, a serine protease expressed specifically in the limbic system of the mouse brain (Chen et al., 1995), and neurotrypsin, a recently characterized serine protease expressed neuronally in high levels in the neocortex, olfactory bulb, hippocampus, amygdala, and brain stem motor nuclei (Gschwend et al., 1997).

\section{Neuroserpin and tPA, a new team on the playground of neuronal plasticity?}

The observation that in many neuronal populations neuroserpin mRNA and protein can be detected in significant amounts not only during development but also in the adult prompts speculations about a function of this serine protease inhibitor in the maintenance of the adult nervous system. Recently, intriguing findings have been made concerning a possible involvement of plasminogen activators in the facilitation of neuronal plasticity. It has been shown that tPA expression and secretion from neurons are regulated by neuronal activity (Qian et al., 1993; Seeds et al., 1995; Gualandris et al., 1996), meeting a criterion commonly proposed for "plasticity-related" proteins. Moreover, it has been demonstrated that tPA has a function in the maintenance of long-lasting LTP in the hippocampus (Frey et al., 1996; Huang et al., 1996), and that a regular performance of animals in learning tasks appears to depend on a balanced expression of plasminogen activators in the brain structures involved (Meiri et al., 1994; Huang et al., 1996). The observation that an overexpression of plasminogen activator in the hippocampus and in the amygdala results in a poor performance in spatial and taste aversion tasks
(Meiri et al., 1994) argues in favor of a potential relevance of an inhibitor of plasminogen activators in these processes. Both the inhibitory specificity and the spatial distribution of expression are consistent with a function of neuroserpin in this context. Neuroserpin can inhibit the proteolytic activity of tPA. Moreover, it is most abundantly expressed in neurons of CNS regions that have been shown to display a high degree of plasticity, i.e., the neocortex (Gilbert, 1992; Merzenich and Sameshima, 1993), the hippocampal formation (Ben-Ari and Represa, 1990; Larkman and Jack, 1995), the olfactory formation (Sullivan et al., 1995), and the amygdala (Maren and Fanselow, 1996). Despite the cellular and molecular mechanisms by which tPA exerts its functions being ill-defined, and although an involvement of neuroserpin in the modulation of synaptic efficacy or structural changes associated with learning remains to be demonstrated, it is tempting to speculate that neuroserpin and tPA are complementary proteins in the facilitation of neuronal plasticity.

\section{REFERENCES}

Altman J, Bayer SA (1985a) Embryonic development of the rat cerebellum. II. Translocation and regional distribution of the deep neurons. J Comp Neurol 231:27-41.

Altman J, Bayer SA (1985b) Embryonic development of the rat cerebellum. III. Regional differences in the time of origin, migration, and settling of Purkinje cells. J Comp Neurol 231:42-65.

Altman J, Bayer SA (1989) Development of the rat thalamus: IV. The intermediate lobule of the thalamic neuroepithelium, and the time and site of origin and settling pattern of neurons of the ventral nuclear complex. J Comp Neurol 284:534-566.

Ben-Ari Y, Represa A (1990) Brief seizure episodes induce long-term potentiation and mossy fibre sprouting in the hippocampus. Trends Neurosci 13:312-318.

Chen ZL, Yoshida S, Kato K, Momota Y, Suzuki J, Tanaka T, Ito J, Nishino H, Aimoto S, Kiyama H, Shiosaka S (1995) Expression and activity-dependent changes of a novel limbic-serine protease gene in the hippocampus. J Neurosci 15:5088-5097.

Chomczynski P, Sacchi N (1987) Single-step method of RNA isolation by acid guanidinium thiocyanate-phenol-chloroform extraction. Anal Biochem 162:156-159.

Dent MA, Sumi Y, Morris RJ, Seeley PJ (1993) Urokinase-type plasminogen activator expression by neurons and oligodendrocytes during process outgrowth in developing rat brain. Eur J Neurosci 5:633-647.

Dihanich M, Kaser M, Reinhard E, Cunningham D, Monard D (1991) Prothrombin mRNA is expressed by cells of the nervous system. Neuron 6:575-581.

Fazekas de St. Groth S, Scheidegger D (1980) Production of monoclonal antibodies: strategy and tactics. J Immunol Methods 35:1-21.

Frey U, Muller M, Kuhl D (1996) A different form of long-lasting potentiation revealed in tissue plasminogen activator mutant mice. J Neurosci 16:2057-2063.

Friedman GC, Seeds NW (1995) Tissue plasminogen activator mRNA expression in granule neurons coincides with their migration in the developing cerebellum. J Comp Neurol 360:658-670.

Gilbert CD (1992) Horizontal integration and cortical dynamics. Neuron 9:1-13.

Gloor S, Odink K, Guenther J, Nick H, Monard D (1986) A glia-derived neurite promoting factor with protease inhibitory activity belongs to the protease nexins. Cell 47:687-693.

Gschwend TP, Krueger SR, Kozlov SV, Wolfer DP, Sonderegger P (1997) Neurotrypsin, a novel multidomain serine protease expressed in the nervous system. Mol Cell Neurosci 9:207-219.

Gualandris A, Jones TE, Strickland S, Tsirka SE (1996) Membrane depolarization induces calcium-dependent secretion of tissue plasminogen activator. J Neurosci 16:2220-2225.

Guenther J, Nick H, Monard D (1985) A glia-derived neurite-promoting factor with protease inhibitory activity. EMBO J 4:1963-1966.

Gurwitz D, Cunningham DD (1988) Thrombin modulates and reverses neuroblastoma neurite outgrowth. Proc Natl Acad Sci USA 85:3440-3444.

Gurwitz D, Cunningham DD (1990) Neurite outgrowth activity of pro- 
tease nexin-1 on neuroblastoma cells requires thrombin inhibition. J Cell Physiol 142:155-162.

Hantaï D, Rao JS, Kahler C, Festoff BW (1989) Decrease in plasminogen activator correlates with synapse elimination during neonatal development of mouse skeletal muscle. Proc Natl Acad Sci USA 86:362-366.

Huang YY, Bach ME, Lipp HP, Zhuo M, Wolfer DP, Hawkins RD, Schoonjans L, Kandel ER, Godfraind JM, Mulligan R, Collen D, Carmeliet P (1996) Mice lacking the gene encoding tissue-type plasminogen activator show a selective interference with late-phase longterm potentiation in both Schaffer collateral and mossy fiber pathways. Proc Natl Acad Sci USA 93:8699-8704.

Kozak M (1987) An analysis of 5' -noncoding sequences from 699 vertebrate messenger RNAs. Nucleic Acids Res 15:8125-8148.

Krebber A, Bornhauser S, Burmester J, Honegger A, Willuda J, Bosshard HR, Plückthun A (1997) Reliable cloning of functional antibody variable domains from hybridomas and spleen cell repertoires using a reengineered phage display system. J Immunol Methods 201:35-55.

Krystosek A, Seeds NW (1981) Plasminogen activator release at the neuronal growth cone. Science 213:1532-1534.

Krystosek A, Seeds NW (1984) Peripheral neurons and Schwann cells secrete plasminogen activator. J Cell Biol 98:773-776.

Larkman AU, Jack JJ (1995) Synaptic plasticity: hippocampal LTP. Curr Opin Neurobiol 5:324-334.

Liu Y, Fields RD, Festoff BW, Nelson PG (1994) Proteolytic action of thrombin is required for electrical activity-dependent synapse reduction. Proc Natl Acad Sci USA 91:10300-10304.

Lund RD, Mustari MJ (1977) Development of the geniculocortical pathway in rats. J Comp Neurol 173:289-306.

Mansuy IM, van der Putten H, Schmid P, Meins M, Botteri FM, Monard D (1993) Variable and multiple expression of Protease Nexin-1 during mouse organogenesis and nervous system development. Development 119:1119-1134.

Maren S, Fanselow MS (1996) The amygdala and fear conditioning-has the nut been cracked? Neuron 16:237-240.

Meiri N, Masos T, Rosenblum K, Miskin R, Dudai Y (1994) Overexpression of urokinase-type plasminogen activator in transgenic mice is correlated with impaired learning. Proc Natl Acad Sci USA 91:3196-3200.

Merzenich MM, Sameshima K (1993) Cortical plasticity and memory. Curr Opin Neurobiol 3:187-196.

Moonen G, Grau-Wagemans MP, Selak I (1982) Plasminogen activatorplasmin system and neuronal migration. Nature 298:753-755.

Osterwalder T, Contartese J, Stoeckli ET, Kuhn TB, Sonderegger P (1996) Neuroserpin, an axonally secreted serine protease inhibitor. EMBO J 15:2944-2953.

Pittman RN, DiBenedetto AJ (1995) PC12 cells overexpressing tissue plasminogen activator regenerate neurites to a greater extent and migrate faster than control cells in complex extracellular matrix. J Neurochem 64:566-575.

Pittman RN, Ivins JK, Buettner HM (1989) Neuronal plasminogen activators: cell surface binding sites and involvement in neurite outgrowth. J Neurosci 9:4269-4286.

Potempa J, Korzus E, Travis J (1994) The serpin superfamily of proteinase inhibitors: structure, function, and regulation. J Biol Chem 269:15957-15960.

Qian Z, Gilbert ME, Colicos MA, Kandel ER, Kuhl D (1993) Tissueplasminogen activator is induced as an immediate-early gene during seizure, kindling and long-term potentiation. Nature 361:453-457.
Sambrook J, Fritsch EF, Maniatis T (1989) Molecular cloning: a laboratory manual. Cold Spring Harbor, NY: Cold Spring Harbor Laboratory.

Sappino AP, Madani R, Huarte J, Belin D, Kiss JZ, Wohlwend A, Vassalli JD (1993) Extracellular proteolysis in the adult murine brain. J Clin Invest 92:679-685.

Schaeren-Wiemers N, Gerfin-Moser A (1993) A single protocol to detect transcripts of various types and expression levels in neural tissue and cultured cells: in situ hybridization using digoxigenin-labeled cRNA probes. Histochemistry 100:431-440.

Schapira M, Patson PA (1991) Serine protease inhibitors (Serpins). Trends Cardiovasc Med 1:146-151.

Schechter I, Berger A (1967) On the size of the active site in proteases. I. Papain. Biochem Biophys Res Commun 27:157-162.

Schrimpf SP, Bleiker AJ, Brecevic L, Kozlov SV, Berger P, Osterwalder T, Krueger SR, Schinzel A, Sonderegger P (1997) Human neuroserpin (PI12) - cDNA cloning and chromosomal localization to 3q26. Genomics 40:55-62.

Seeds NW, Haffke S, Christensen K, Schoonmaker J (1990) Cerebellar granule cell migration involves proteolysis. Adv Exp Med Biol 265:169-178.

Seeds NW, Williams BL, Bickford PC (1995) Tissue plasminogen activator induction in Purkinje neurons after cerebellar motor learning. Science 270:1992-1994.

Stoeckli ET, Lemkin PF, Kuhn TB, Ruegg MA, Heller M, Sonderegger P (1989) Identification of proteins secreted from axons of embryonic dorsal-root-ganglia neurons. Eur J Biochem 180:249-258.

Sullivan SL, Ressler KJ, Buck LB (1995) Spatial patterning and information coding in the olfactory system. Curr Opin Genet Dev 5:516-523.

Sumi Y, Dent MA, Owen DE, Seeley PJ, Morris RJ (1992) The expression of tissue and urokinase-type plasminogen activators in neural development suggests different modes of proteolytic involvement in neuronal growth. Development 116:625-637.

Theiler K (1989) The house mouse: atlas of embryonic development. New York: Springer.

Thewke DP, Seeds NW (1996) Expression of hepatocyte growth factor/ scatter factor, its receptor, c-met, and tissue-type plasminogen activator during development of the murine olfactory system. J Neurosci 16:6933-6944.

Tsirka SE, Rogove AD, Bugge TH, Degen JL, Strickland S (1997) An extracellular proteolytic cascade promotes neuronal degeneration in the mouse hippocampus. J Neurosci 17:543-552.

von Heijne G (1983) Patterns of amino acids near signal-sequence cleavage sites. Eur J Biochem 133:17-21.

von Heijne G (1985) Signal sequences. The limits of variation. J Mol Biol 184:99-105.

Ware JH, Dibenedetto AJ, Pittman RN (1995) Localization of tissue plasminogen activator mRNA in adult rat brain. Brain Res Bull 37:275-281.

Wentworth LE (1984a) The development of the cervical spinal cord of the mouse embryo. I. A Golgi analysis of ventral root neuron differentiation. J Comp Neurol 222:81-95.

Wentworth LE (1984b) The development of the cervical spinal cord of the mouse embryo. II. A Golgi analysis of sensory, commissural, and association cell differentiation. J Comp Neurol 222:96-115. 